\title{
C-reactive protein in juvenile chronic arthritis: an indicator of disease activity and possibly amyloidosis
}

\author{
M. GWYTHER, H. SCHWARZ, ${ }^{*}$ A. HOWARD, AND BARBARA M. ANSELL
}

From the Clinical Research Centre, Division of Rheumatology, Northwick Park Hospital, Harrow, Middlesex HA1 3UJ

SUMMARY C-reactive protein (CRP) was found to be particularly high early in the course of those cases of juvenile chronic arthritis (JCA) with a systemic onset, the mean level being $12 \mathrm{mg} / \mathrm{dl}$ (120 $\mathrm{mg} / \mathrm{l})$. It was also raised in cases with a polyarticular onset, mean level $6 \mathrm{mg} / \mathrm{dl}$, while in cases with a pauciarticular onset it was associated with only a modest increase up to $1.5 \mathrm{mg} / \mathrm{dl}(15 \mathrm{mg} / \mathrm{l})$. At the onset of disease there was a good correlation with the erythrocyte sedimentation rate (ESR). Regression of systemic disease was associated with a steady fall in C-reactive protein, but those patients who developed anıyloidosis within 5 years from onset had persistently high values until cytotoxic therapy was introduced. Patients who developed amyloidosis later tended to have high CRP levels in the months or even years before diagnosis. In a few patients with polyarthritis the CRP appeared to reflect severe disease more closely than their relatively low ESR.

C-reactive protein is an acute-phase protein which rapidly increases a thousand-fold or more in response to inflammation and tissue damage. Both in adult rheumatoid arthritis ${ }^{12}$ and in ankylosing spondylitis ${ }^{3}$ it may well be a more sensitive parameter of disease activity than the conventional erythrocyte sedimentation rate. In juvenile chronic arthritis only scant information is available. ${ }^{4}$ It was therefore decided to investigate the level of CRP early in the course of the disease.

\section{Materials and methods}

A single serum sample was obtained from 60 children with juvenile chronic arthritis seen early in the course of their disease. The children were subgrouped according to the mode of onset of the disease. For patients with a systemic onset the characteristic fever and rash were required, which could be accompanied by pericarditis, hepatomegaly, splenomegaly, or generalised lymphadenopathy. A polyarthritic onset required 5 or more joints to be affected in the first 3 months in the absence of serious systemic features,

Accepted for publication 2 June 1981.

*Rheumatologische Universitätspoliklinik Inselspital, 3010 Bern, Switzerland.

Correspondence to Dr Barbara M. Ansell. while a pauciarticular onset had fewer than 5 joints affected, often asymmetrically distributed during the first 3 months. ${ }^{5}$ There were 20 patients in each such group, of whom all the children with systemic illness were seen within a few months of their first symptoms, as were 16 of the polyarthritic and 15 of the pauciarticular patients. The remainder were seen slightly later. Serial samples over a period of 2-6 years were available from 30 patients with either systemic or polyarticular disease. Twelve of this group developed amyloidosis confirmed by biopsy during the period for which specimens were available.

Sera were collected and stored at $-20^{\circ} \mathrm{C}$ until estimation. The CRP levels were measured by the Fahey modification of the Mancini radial immunodiffusion technique. ${ }^{6}$ The plates were dried and

Table 1 C-reactive protein levels at onset in subgroups of JCA

\begin{tabular}{llcl}
\hline Mode of onset & $\begin{array}{l}\text { No. of } \\
\text { patients }\end{array}$ & $\begin{array}{l}\text { Mean CRP } \\
\text { mg/dl }\end{array}$ & Range mg/dl \\
\hline Pauciarticular & 20 & 1.45 & $0 \cdot 1-9 \cdot 3$ \\
Polyarticular & 20 & 5.97 & $0 \cdot 1-22.0$ \\
Systemic & 20 & 12.03 & $1 \cdot 9-46.0$ \\
\hline
\end{tabular}

Normal range: $0.01-0.8 \mathrm{mg} / \mathrm{dl}$ Median: $0.06 \mathrm{mg} / \mathrm{dl}$. SI conversion: $\mathrm{mg} / \mathrm{l}=\mathrm{mg} / \mathrm{dl}$ $\times 10$. 


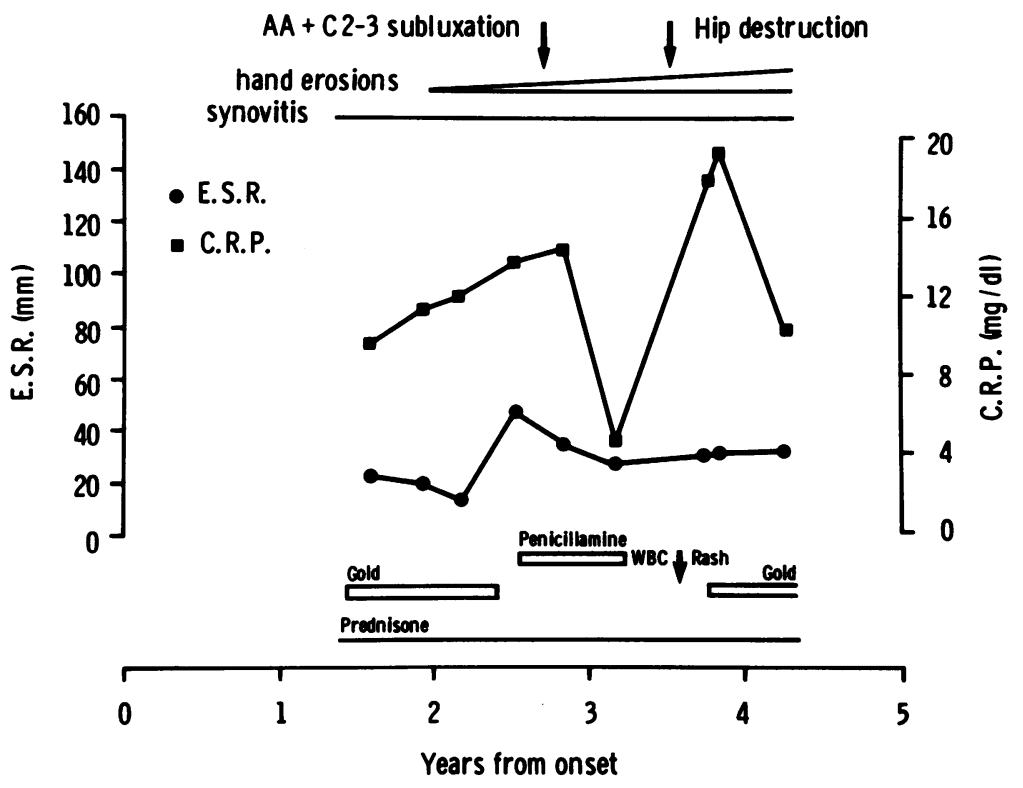

Fig. 1 Female. Systemic onset aged 10 years followed by destructive arthropathy with atlanto-axial subluxation. In this patient despite the progressive arthropathy the ESR was relatively low.

stained with Coomassie blue before they were read. The agarose used was Indubiose A37, Code 3022, from l'Industrie Biologique Française, 92115 Clichy, and the monospecific anti-CRP was from DakoImmunoglobulins Ltd, Copenhagen. The reference serum used was ORCE 02/03 from Hoechst UK Ltd. ESR levels were the routine measurement made by the hospital laboratory using the Westergren technique.

\section{Results}

Those children with a systemic onset of juvenile chronic arthritis had significantly higher levels than those with a polyarticular onset (Student's $t$ test, $\mathrm{p}<0.01$, Table 1). Those with a pauciarticular onset generally had low levels, though the range was fairly wide. There was a good correlation between the ESR and the level of $\mathrm{C}$-reactive protein in all these patients. In 18 children a minimum of 6 serial measurements were made over a 2-5 year period. The correlation between ESR and C-reactive protein was usually good in the systemic illness subgroup $(r=$ $0.79)$, and in the polyarthritic group $(r=0.75)$, though in 3 of the $11(\mathrm{r}=0.22)$ it appeared to reflect the very serious destructive nature of their illness better than their relatively low ESR (Fig. 1). The
Fig. 2 Female. Systemic onset at 1 year 1 month. Gradual improvement so that she was in clinical remission by 5 years.

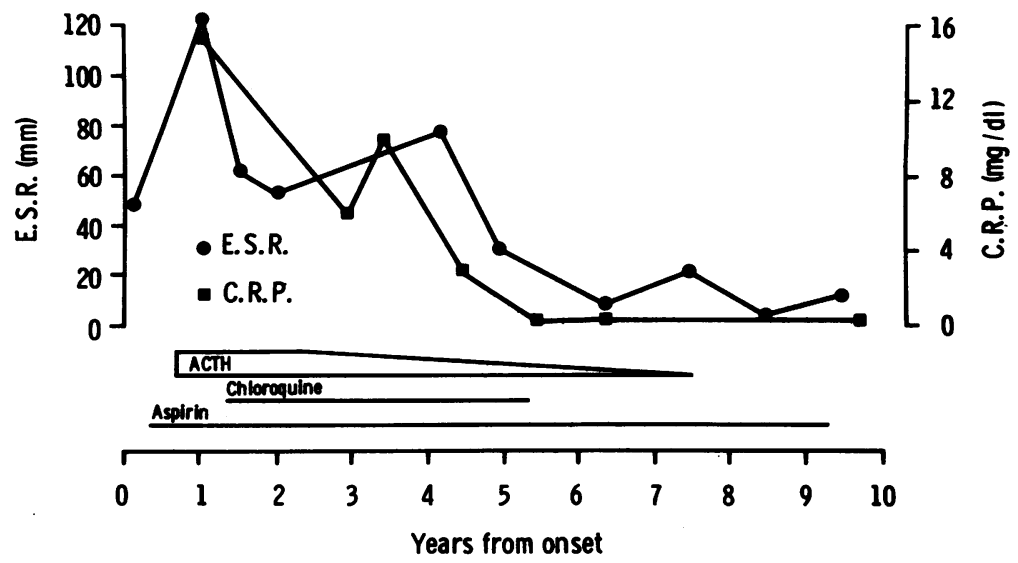




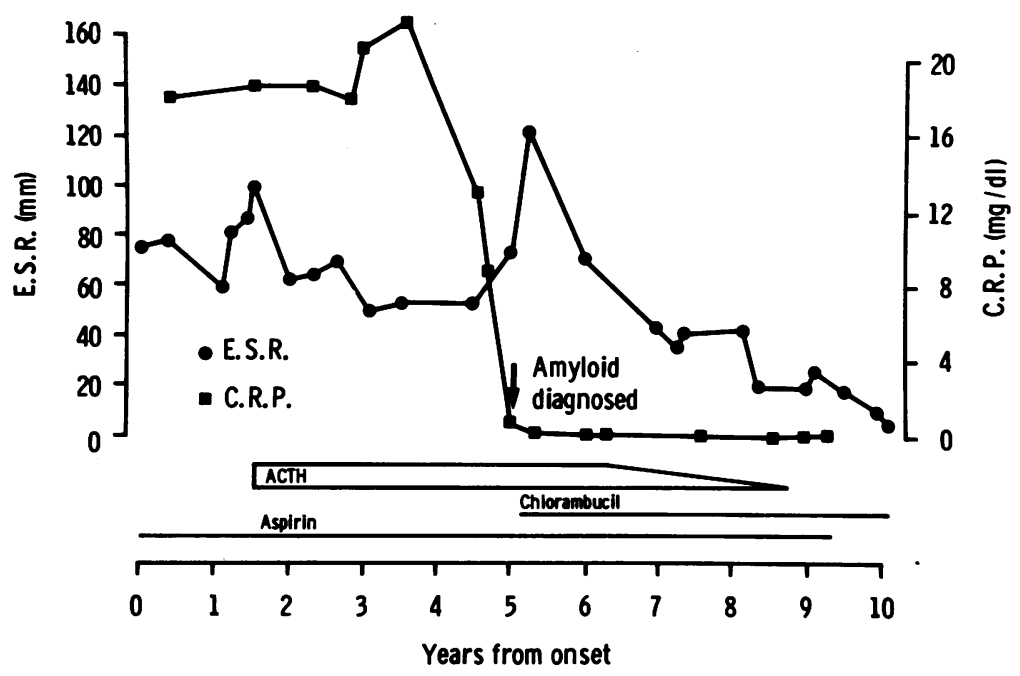

Fig. 3 Female. Systemic onset at 3 years 10 months. Managed in a similar fashion to patient in Fig. 2, but activity persisted with the development of amyloidosis in year 4-5 of her illness. Note the persistently high $C R P$ initially.

CRP and ESR levels tended to fall in those with systemic illness when their disease started to improve, possibly as the result of therapy (Fig. 2). However, in the 5 patients in whom amyloidosis developed within 5 years of systemic onset the C-reactive protein has remained consistently high, and the correlation with the ESR was not as good (Figs. 3 and 4). Seven further patients in whom amyloidosis developed later in the course of the illness, for whom serial samples were available from our serum bank, showed similar high levels of CRP over months and in some cases years before the diagnostic confirmation by biopsy (Fig. 5).

\section{Discussion}

C-reactive protein is a normal, $0 \cdot 01-0.8 \mathrm{mg} / \mathrm{dl}$ $(0 \cdot 1-8 \cdot 0 \mathrm{mg} / \mathrm{l})$, constituent of serum produced in the liver. Its function is unknown, ${ }^{7}$ but high levels are found during acute infections, tissue injury including surgical, and in inflammatory disease. Its response to these factors is very rapid; within a period of hours it can reach 100-fold normal levels, and it does not appear to be affected by drugs except in so far as they affect the underlying causes of the CRP production. In the rheumatic diseases it appears to correlate well with the ESR but has several advantages as a diagnos-
Fig. 4 Mean CRP levels in 2 groups of 5 patients each with systemic illness. The top line represents those becoming amyloidotic, the lower represents those in remission at 5 years.

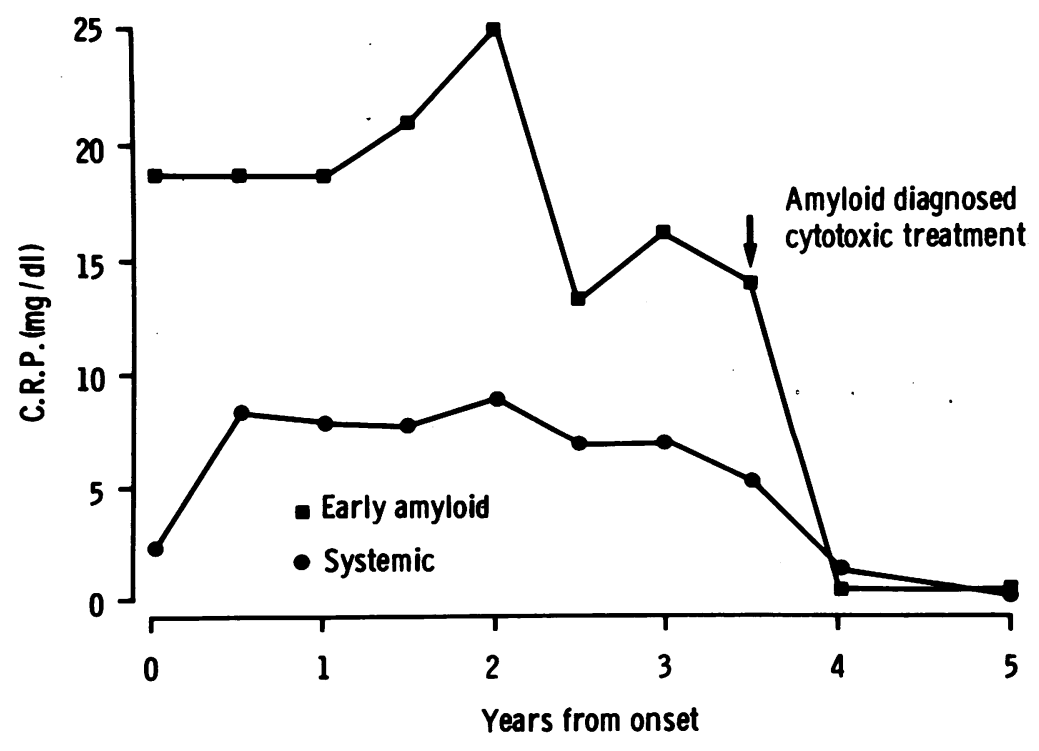




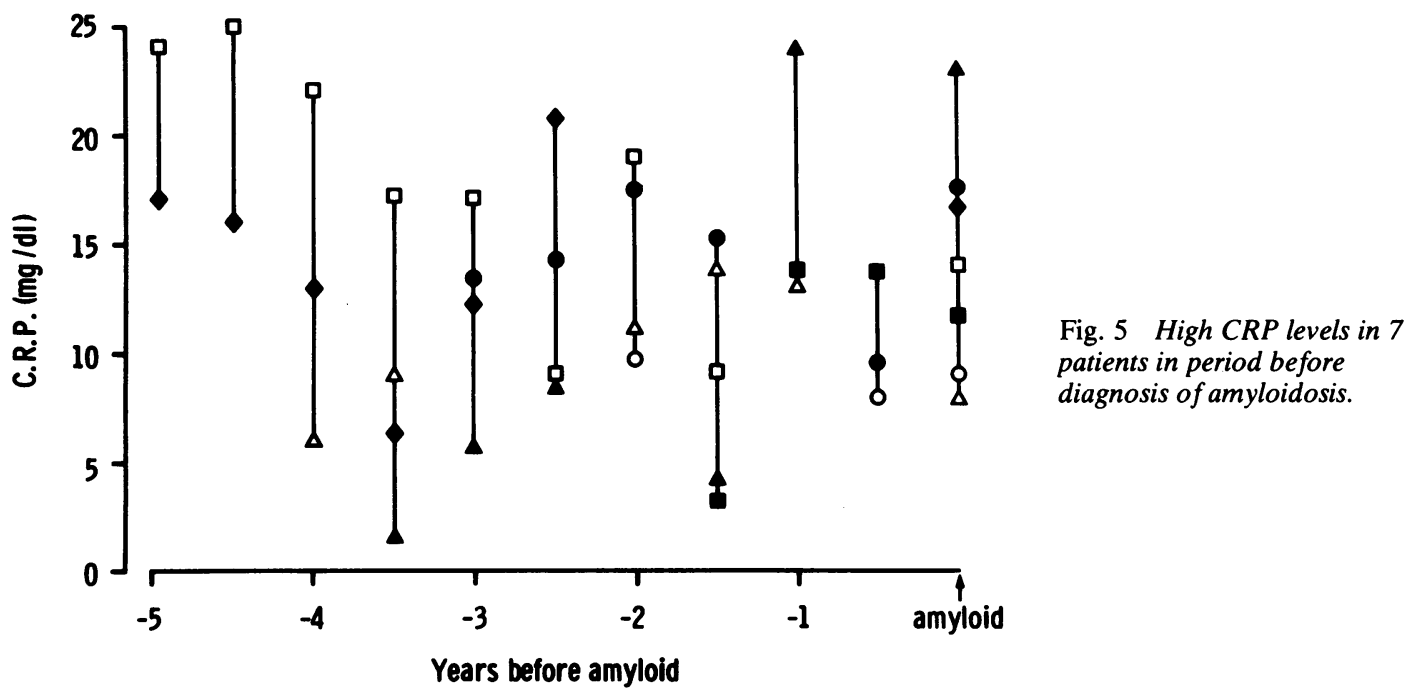

(Symbols represent individual patients)

tic test. These include the speed of its response to inflammation, the fact that it is not affected by variations in plasma constituents, and in young children only small amounts of blood are required for serial estimation as compared with the conventional ESR. However, the 2 tests must still be regarded as complementary, at least in the initial assessment of children with arthritis, as patients with systemic lupus erythematosus tend to have low CRP levels with high ESR. ${ }^{8}$

As an indicator of the response to therapy in our group of JCA patients the CRP level gave more meaningful information. In a few treated with gold or penicillamine the CRP reflected their continuing activity with radiological deterioration better than the ESR. In our systemic group several patients who persisted with high CRP levels, which were not lowered by conventional therapy over a period of years, became amyloidotic, while a further number with long-term illness had high levels of CRP for months or often years before the biopsy-proved diagnosis of amyloidosis. The level of CRP in both these groups fell dramatically after the start of cytotoxic therapy.

The serum-related amyloid $P$ protein, which has considerable homologies of amino acid sequence with CRP, a similar pentarmeric structure, and has the same ability to bind to polymers through $\mathrm{Ca}^{++}$, is also raised in these JCA patients, though not as dramatically as is the CRP; it also falls, but at a slower rate, on cytotoxic therapy. Whether this could be a better indicator of response to therapy in these cases is being investigated.

\section{References}

1 Walsh L, Davies P, McConkey B. Relationship between erythrocyte sedimentation rate and $\mathrm{C}$-reactive protein in rheumatoid arthritis. Ann Rheum Dis 1979; 38: 362-3.

${ }^{2}$ Amos R S, Constable T J, Crockson R A, Crockson A P, McConkey B. Rheumatoid arthritis; relation of serum $C$-reactive protein and erythrocyte sedimentation rate to radiographic changes. $B r$. Med J 1977; i: 195-7.

${ }^{3}$ Cowling P, Ebringer R, Cawdell D, Ishii M, Ebringer A. C-reactive protein, ESR, and klebsiella in ankylosing spondylitis. Ann Rheum Dis 1980; 39: 45-9.

4 Mellbye Ove J, Hoyeraal Hans M, Froland Stig S. C-reactive protein and delayed hypersensitivity in juvenile rheumatoid arthritis. Scand J Rheumatol 1978; 7: 90-2.

's Munthe E, ed. The Care of Rheumatic Children. Basle: Eular, 1978.

- Fahey J L, McKelvey E M. Quantitative determination of serum immunoglobulins in antibody agar plates. J Immunol 1965; 94: 84-90.

7 Pepys M B. C-reactive protein fifty years on. Lancet 1981; i: 653-7.

8 Caeiro F, Michilson F, Bernstein R, Hughes G R V, Ansell B M. Systemic lupus erythematosus in childhood. Ann Rheum Dis in press. 